\title{
Investigating proximate composition and fatty acid profile of Longissimus dorsi from Anatolian Water Buffaloes (Bubalus bubalis) raised in similar conditions
}

\author{
Umit GECGEL ${ }^{1 *}$, Ismail YILMAZ ${ }^{1}$, Mehmet Ihsan SOYSAL ${ }^{2}$, Eser Kemal GURCAN², Suleyman KOK ${ }^{3}$
}

\begin{abstract}
The aim of the present study was to compare the proximate analysis and fatty acid profile of water buffalo meats. Samples were taken from three different local meat suppliers in Baklalı, Orcunlu, and Nakkas villages, Istanbul Province, Turkey. Animals were males 24 months old reaching final live weights of 420-440 kg. Significant differences were observed in $\mathrm{pH}$, moisture, fat, color and fatty acid profile of water buffalo meats $(\mathrm{p}<0.05$ and $\mathrm{p}<0.01)$. The results of proximate analysis demonstrated that the $\mathrm{pH}$ (5.03-5.46), moisture (48.60-59.73\%), fat (18.90-30.02\%), ash (2.48-3.56\%), protein (15.12-17.65\%), 'L' lightness (24.38-33.50), 'a' redness (9.88-13.81), and 'b' yellowness (5.66-8.53) were found in the samples. C14:0, C16:0, C18:0, C16:1, C18:1 and C18:2 content of the water buffalo meats were found to be 1.53-4.15\%, 19.99-26.85\%, 19.48-34.50\%, 2.95-5.33\%, 35.37-50.62\%, and 1.02-3.56\%, respectively. The total SFAs, total MUFAs, total PUFAs, and total UFAs contents of the samples ranged between 40.73 and $60.28 \%, 38.32$ and $55.15 \%, 1.34$ and $4.46 \%$, and 39.72 and $59.27 \%$, respectively.
\end{abstract}

Keywords: water buffalo meat; meat quality; fatty acid profile.

Practical Application: A novel meat product can be obtained by using buffalo meat instead of cattle meat.

\section{Introduction}

The buffaloes raised in Turkey originate from Mediterranean buffaloes, which are a subgroup of river buffaloes, known as Anatolian Water Buffaloes. The Anatolian water buffalo is reared for several purposes in Turkey: for draft animal, meat, and milk that may be converted into many various kinds of milk products such as yoghurt, ice cream, ayran, and cheese. According to Turkish Statistical Institute data, 300 tons of meat and 51,947 tons of milk were produced from buffaloes in 2013 (Turkish Statistical Institute, 2014).

The quality and quantity of buffalo meat depend upon several factors such as breed, age, feeding intensity, management system and environmental conditions (Awan et al., 2014). Buffalo meat production in Turkey has become an alternative for the consumption of a lean, lower fat, low cholesterol and tasty product in accordance with the market regarding new trends in meat production. Anatolian Water Buffalo meat is consumed as fresh or in meat products like Turkish style fermented sucuk, sausage, pastrami and salami. In Turkish sausage, water buffalo meat decreases the fermentation duration and improve taste of product. In recent years, there has been a rise in meat production for meat only. Anatolian Water Buffalo meat is more commonly used as a determined percentage together with cattle meat. The importance of the buffalo stems from milk and meat yield resistance to many infectious diseases, low breeding costs, and being an appropriate livestock for low-income growers. In addition to this, the studies have indicated that buffalo meat is leaner and includes less saturated fat, more protein (11\%), less fat (12\%), more minerals (10\%), less cholesterol (40\%) and fewer calories (55\%) compared to beef (Nanda \& Nakao, 2003; Borghese, 2010; Sariozkan, 2011). Therefore, buffalo meat is reported to be a good choice of red meat for people with heart and circulatory system diseases (Kucukkebapci, 2005). Because of these characteristics, there has been increased interest in meat from this species (Irurueta et al., 2008). In particular, buffalo meat seems to be extremely suitable for patients who need dietetical foods (Calabro et al., 2014). Finally, buffalo meat is considered in Turkey as an alternative healthy product because of its good nutritional properties.

The fatty acid composition is one of the most significant determinants of the health quality of meat (Kaczor et al., 2010). In addition, muscle lipids are an important signifier of the nutritional quality of meat (Flynn et al., 1985). At the present time, especially in developed countries, there is an increasing trend in consumers to prefer lean red meat with less fat and high quality (Mushi et al., 2008; Khan \& Iqbal, 2009). The fatty acid profile of buffalo fat affects the nutritional value of the meat, different aspects of meat quality, flavor content and shelf life (Lambertz et al., 2014). On the other hand, the structure of the fatty acids plays an important role in maintaining health (Williams, 2000). Moreover, the ratio between polyunsaturated and saturated fatty acids (P:S) and the ratio between omega $6(n-6)$ and omega $3(n-3)$ fatty acids are taken into account as two significant indices for the nutritional evaluation of fat, and these ratios are highly important for human health (Department of Health, 1994; Raes et al., 2004). 
The scientific literature concerning the description of the proximate and fatty acid profile of water buffalo meat is limited. To the best of our knowledge, no study about the fatty acid composition and omega fatty acids of water buffalo meat in Turkey has been done. For this reason, the objective of the present study was to determine some quality parameters and fatty acid composition of longissimus dorsi from Anatolian water buffaloes under similar conditions, harvested at 24 months of age, and from animals grown in Marmara (Thrace) region, Turkey. The results of the study could be also used as a guide for nutritionists and shoppers and to raise their information about the meat quality, omega fatty acids, and fatty acid profile of water buffalo meat.

\section{Materials and methods}

\subsection{Materials}

According to the state statistics institution, 121,826 head of water buffalo existed in Turkey in 2014. The number of buffaloes in Istanbul province is 10,853 spread around the districts of Catalca, Arnavutkoy, Eyup, Kagithane and raised by 254 farms (Turkish Statistical Institute, 2014). Samples were taken from local meat suppliers contracted with farmers and the sampling was organized as 12 male 24 month aged individuals raised in Baklalı village (four head; Sample No:1-4) of Arnavutkoy district and Orcunlu (four head; Sample No:5-8), Nakkas village and (four head; Sample No:9-12), of Catalca district of Istanbul province in Marmara region. Environmental conditions including feeding regime and farming practices were the same. All animals were weaned at six months of age. After calving, all calves received mother's milk up to $10 \%$ of the body weight of the calf averaging $4 \mathrm{~kg}$ milk per day and remained to gather with the mother. After two weeks of age calves were transferred to individual pens and exercised to receive low amounts of starter feed concentrates containing $18 \%$ protein. The amount of concentrates gradually increased up to $3 \mathrm{~kg}$ per day until six months of age. From six months to slaughtering age, animals received $1 \mathrm{~kg}$ hay, $3 \mathrm{~kg}$ concentrates (18\% protein content), $4 \mathrm{~kg}$ corn silage, and $1 \mathrm{~kg}$ of middling crushed bran or barley and were kept in closed barns. After slaughtering, the samples were received as $\mathbf{5 0 0}$ gram meat from the buttock and longissimus dorsi and were subjected to analysis.

\subsection{Proximate analysis}

Moisture, a crude fat and ash content of water buffalo meat was determined according to the guidelines of Association of Official Analytical Chemists (2005), while the protein content (as Kjeldahl nitrogen) was determined according to Association of Official Analytical Chemists (1990) official methods. The $\mathrm{pH}$ values of samples were determined using a $\mathrm{pH}$ meter according to the method of Du \& Ahn (2002).

DP-900 D25-A color meter (Hunter Lab Associates, Reston, VA, USA) was used to determine the Hunter $\mathrm{L}, \mathrm{a}, \mathrm{b}$ color scales and meat color evaluation was performed according to Setser (1984). An Instron universal testing machine (Model 1140, Instron Co., Buckinghamshire, England) equipped with a blade was used to determine the firmness of water buffalo meats using a $500 \mathrm{~kg}$ load at $20 \mathrm{~mm} / \mathrm{min}$ (Bloukas \& Paneras, 1993).

\subsection{Fat Extraction and Fatty Acid Methyl Esters (FAME) Analyses}

$5.0 \pm 0.1 \mathrm{~g}$ taken from water buffalo (M. longissimusdorsi) was weighed and used for further analysis. For fat content determination, lipids were extracted from muscle tissues by the method described by Folch et al. (1957) and Association of Official Analytical Chemists (2005). Meat samples were homogenized by blender with $5 \mathrm{ml}$ of chloroform: methanol $(2: 1, \mathrm{v} / \mathrm{v})$ and analyzed to determine fat content. Lipid extracts were converted to fatty acid methyl esters (FAME) as described by Association of Official Analytical Chemists (1990). FAME was prepared after alkaline hydrolysis, followed by methylation in methanol plus BF3 (14\% boron trifluoride). The final concentration of the FAME was approximately $7 \mathrm{mg} / \mathrm{mL}$ in heptane.

\subsection{GC Condition}

Gas chromatography (GC) analysis was carried out using Hewlett-Packard 6890 model gas chromatograph equipped with a flame ionization detector (FID), and a split injector (Chrompack, Middleburg, The Netherlands). A fused-silica capillary column was used, $\mathrm{CP}^{\mathrm{TM}}$-Sil 88 (Chrompack), $100 \mathrm{~m}$ in length, $0.25 \mathrm{~mm}$ internal diameter, $0.2 \mu \mathrm{m}$ in film thickness. The oven temperature was programmed to an initial temperature of $120^{\circ} \mathrm{C}$ for $1 \mathrm{~min}$, and then increased slowly to $230^{\circ} \mathrm{C}\left(3^{\circ} \mathrm{C} / \mathrm{min}\right)$ and remained at $230^{\circ} \mathrm{C}$ for $20 \mathrm{~min}$. The injector and detector were kept at $250^{\circ} \mathrm{C}$ with gas flows of $40 \mathrm{~mL} / \mathrm{min}$ for hydrogen and $450 \mathrm{~mL} / \mathrm{min}$ for air. Helium was used as a carrier gas at the flow rate of $1 \mathrm{~mL} / \mathrm{min}$. The GC was equipped with a split injector; a single injection volume of $1 \mu \mathrm{L}$ was made per sample duplicate, using a split ratio of 1:100. The peaks were identified by comparing the retention times and area percentages with those of authentic standards of FAMEs obtained from Nu-Chek-Prep Inc. and on the basis of literature data (Pawlowicz \& Drozdowski, 1998). Three replicate GC analyses were carried out, and the results were denoted in $\mathrm{GC}$ area $\%$ as a mean value.

\subsection{Statistical analysis}

For statistical analysis, the collected data on various parameters were subjected to statistical analysis by using completely randomized design. Duncan's multiple range test was applied to compare the difference between the means. The statistical analysis was performed using the SPSS statistical package program (SPSS Inc., 2001).

\section{Results and discussion}

The proximate composition of water buffalo meats is given in Table 1. Fat content of the samples was between 18.90 and $30.02 \%$. A significant difference among buffalo meat samples was observed at the $p<0.01$ level of significance. These differences were affected by various factors such as breed, genotypes, diet, sex, and feeding system, therefore these differences were expected. The moisture content of all the buffalo meat samples was found to be $48.60-59.73 \%$. Awan et al. (2014) noticed that usually fat and moisture in the meat were inversely related. Similarly, Lawrie (1998) reported that the moisture content of buffalo meat decreased, which was presumably connected with 
Table 1. Proximate composition of water buffalo meats (Mean \pm SEM).

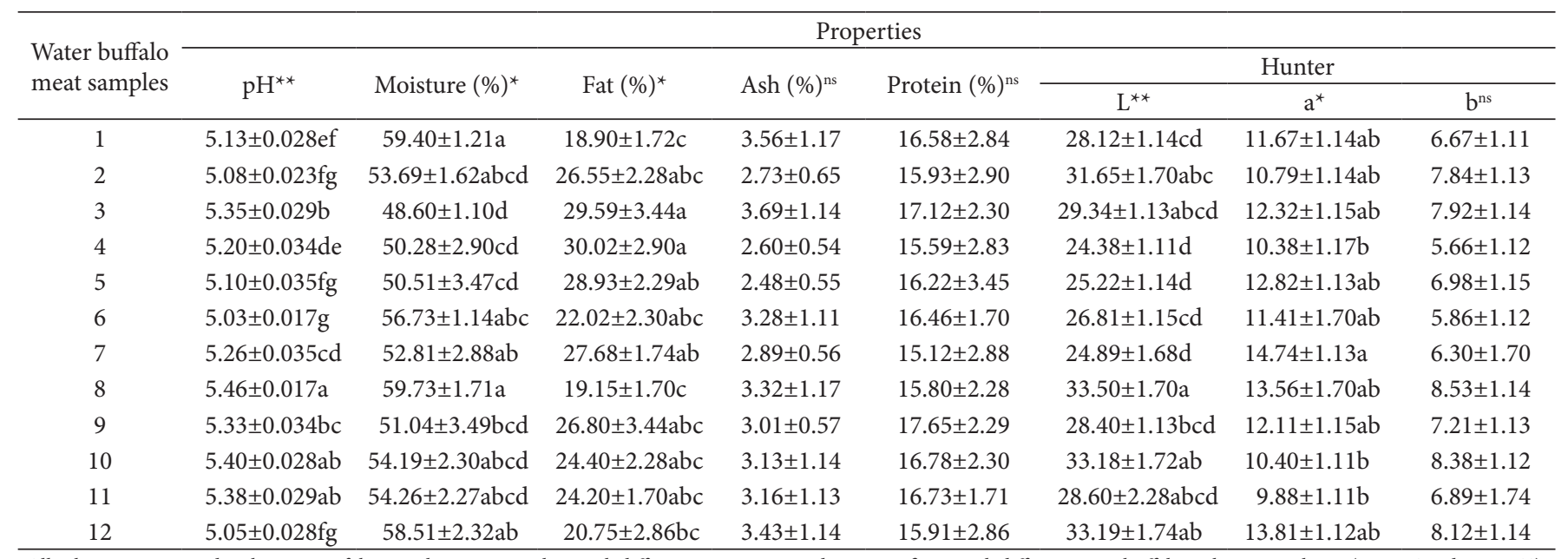

All values are expressed as the means of three replicates; a-g: Values with different superscripts indicate significant with different water buffalo in the same column $\left(p<0.05^{\star}\right.$ and $\left.\mathrm{p}<0.01^{\star *}\right)$; ns: non-significant. L value indicates the level of dark or light, a value redness or greenness, b value yellowness or blueness.

an increase in fat content. Moisture and fat results of the current research support these statements. According to the results in Table 1, the lowest percentages of moisture (48.60 and 50.28\%) versus the highest percentages of fat (29.59 and 30.02\%) and the highest percentages of moisture (59.40-59.73\%) versus the lowest percentages of fat (18.90 and 19.15\%) were obtained. The differences in fat and moisture contents might be partly because of the higher carcass weight of the concentrate-fed animals (Lambertz et al., 2014). The protein content (\%) and ash content (\%) were in the ranges of 15.12-17.65, and 2.48-3.69, respectively. Awan et al. (2014) obtained similar protein results in the buffalo meat samples in different age groups. However, the protein results were lower than those reported by Juarez et al. (2010), Calabro et al. (2014), and Lambertz et al. (2014). Results for protein and ash percentage in these buffalo meat samples were found to be non-significant at the level of $\mathrm{p}>0.05$. The $\mathrm{pH}$ at $24 \mathrm{~h}$ after slaughtering was comparable in the buffalo meat samples (5.03 vs. 5.46). The $\mathrm{pH}$ range found in the current study was similar to the findings by Spanghero et al. (2004), and Calabro et al. (2014). However, this $\mathrm{pH}$ value was lower than those reported by Awan et al. (2014), and Lambertz et al. (2014). pH is an outcome of post mortem biochemical changes that continue in the course of the storage period and are directly connected to storage temperature (Awan et al., 2014).

Meat color ranges from nearly white to dark red according to the species, anatomical location, pigment concentration, nutrition state, age and gender. In addition, post-mortem factors such as the rate of $\mathrm{pH}$ fall, oxidation processes, packaging, temperature and lighting during storage and display, and also the microbial load have a great influence on meat color (Ponce-Alquicira \& Quintero-Salazar, 2009). The 'L' values of meat ranged from 24.38 to 33.50 . The differences among the ' $\mathrm{L}$ ' values of the meats were significant $(p<0.05)$. The highest ' $L$ ' (lightness) values (33.50) were obtained from the sample eight in Table 1. Color was also greatly affected by changes in muscle $\mathrm{pH}$. As the ultimate $\mathrm{pH}$ increases, the meat gradually became darker. Values for ' $a$ ' (redness) were also different $(\mathrm{p}<0.05)$ for the samples. The 'a' values of meat ranged from 9.88 to 14.74 . No significant differences in ' $b$ ' (yellowness) value among the samples $(\mathrm{p}>0.05)$ were found.

Fatty acid profiles of water buffalo meat samples were presented in Tables 2 and 3. According to the GC analysis of fatty acid methyl esters, oleic acid (C18:1), followed by stearic acid (C18:0), palmitic acid (C16:0), palmitoleic acid (C16:1), and linoleic acid (C18:2) were the major fatty acids, which together comprised approximately $91-92 \%$ of total identified fatty acids. C18:1 content of the water buffalo meat fat varied in the range of $35.37-50.62 \%$. It was followed by C18:0 and C16:0 in the ranges of $17.92-34.50$ and $19.99-26.85 \%$, respectively. In the present study, the contents of C14:0, C16:0, C18:0 and C18:1 were higher than those reported by Calabro et al. (2014) for Italian young male buffaloes. Giuffrida-Mendoza et al. (2015), showed similar proportions of C14:0 and C16:0 fatty acids, and lower proportions of $\mathrm{C} 18: 0$ and $\mathrm{C} 18: 1$ fatty acids than our findings. It has been reported that fatty acid contents of longissimus thoracis from water buffalo meat of $1.84,20.71,13.24$, and $31.56 \%$ for C14:0, C16:0, C18:0, and C18:1 were observed, respectively. The differences in fatty acid composition might be resulted from diet, age of animal, and muscle structure.

SFA content of samples was found between 40.73 and $60.28 \%$ $(\mathrm{p}<0.01)$. Similar results were found in the previous work by Juarez et al. (2010), and Calabro et al. (2014) who reported the values as $54.6 \%$, and $52.5 \%$ in Longissimus thoracis muscle from buffalo meat, respectively. The fat composition of red meat was not recommended as being unhealty for consumers due to the high SFA content (Yousefi et al., 2012). However, it has been emphasized that controlling other diet components (i.e. fructose) is far more significant than SFA intake (Lustig et al., 2012). Therefore, reducing SFAs content in animal products is important for improving the quality of animal products (Rana et al., 2012).

The main SFAs found were C18:0, followed by C16:0 and myristic acid (C14:0), which represented about $98-99 \%$ of the total SFAs in the Longissimus dorsi of water buffalo meats 
Gecgel et al.

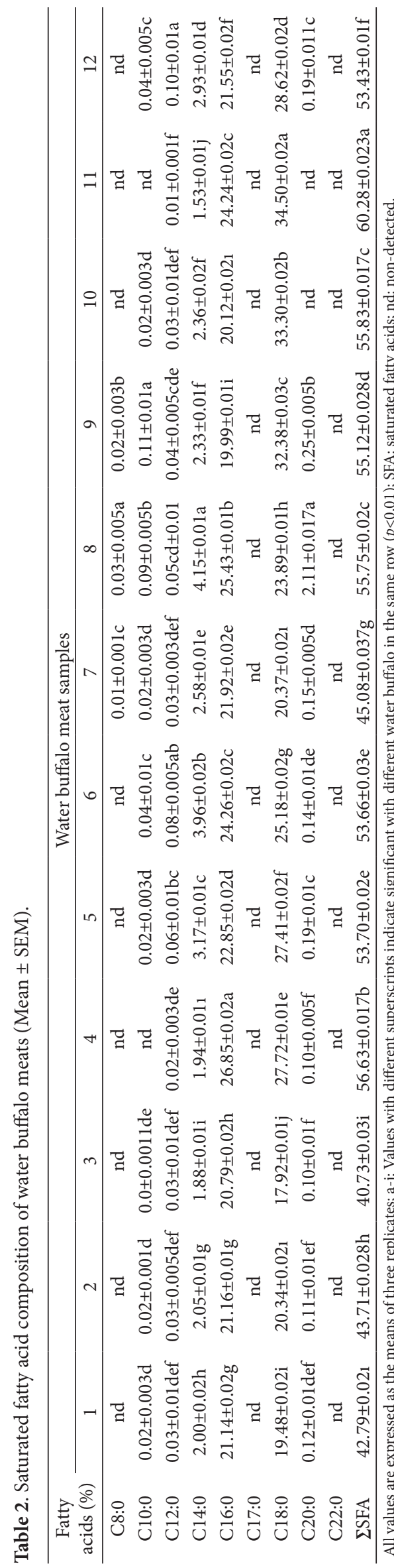

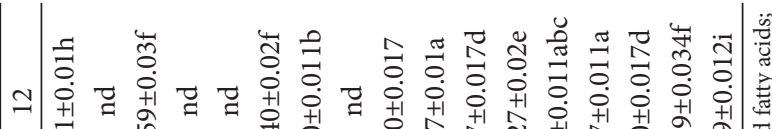

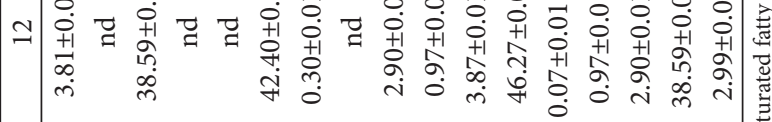

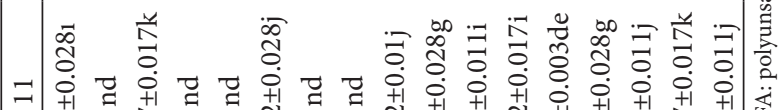

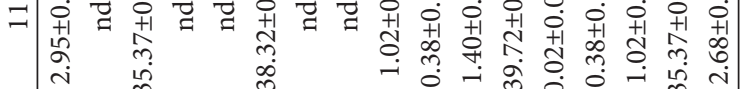

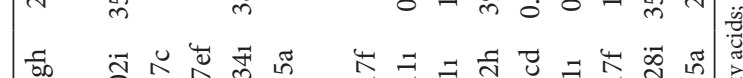

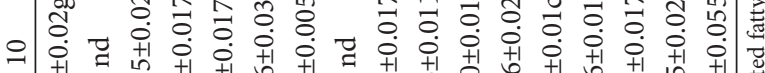

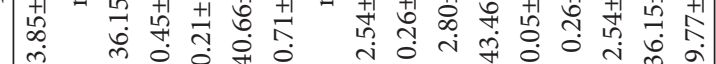

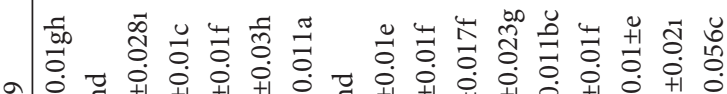

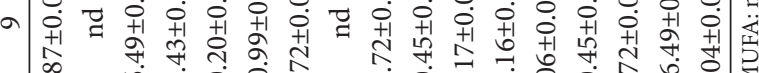

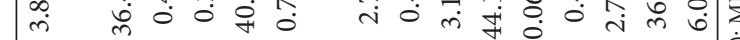

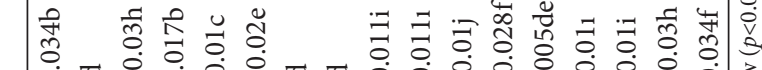

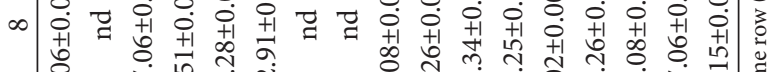

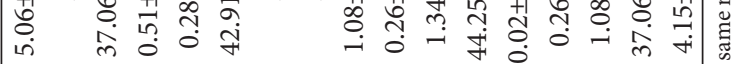

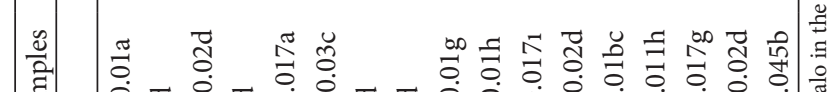

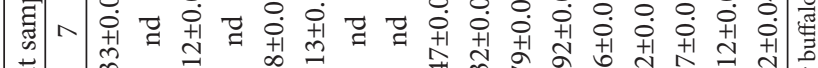

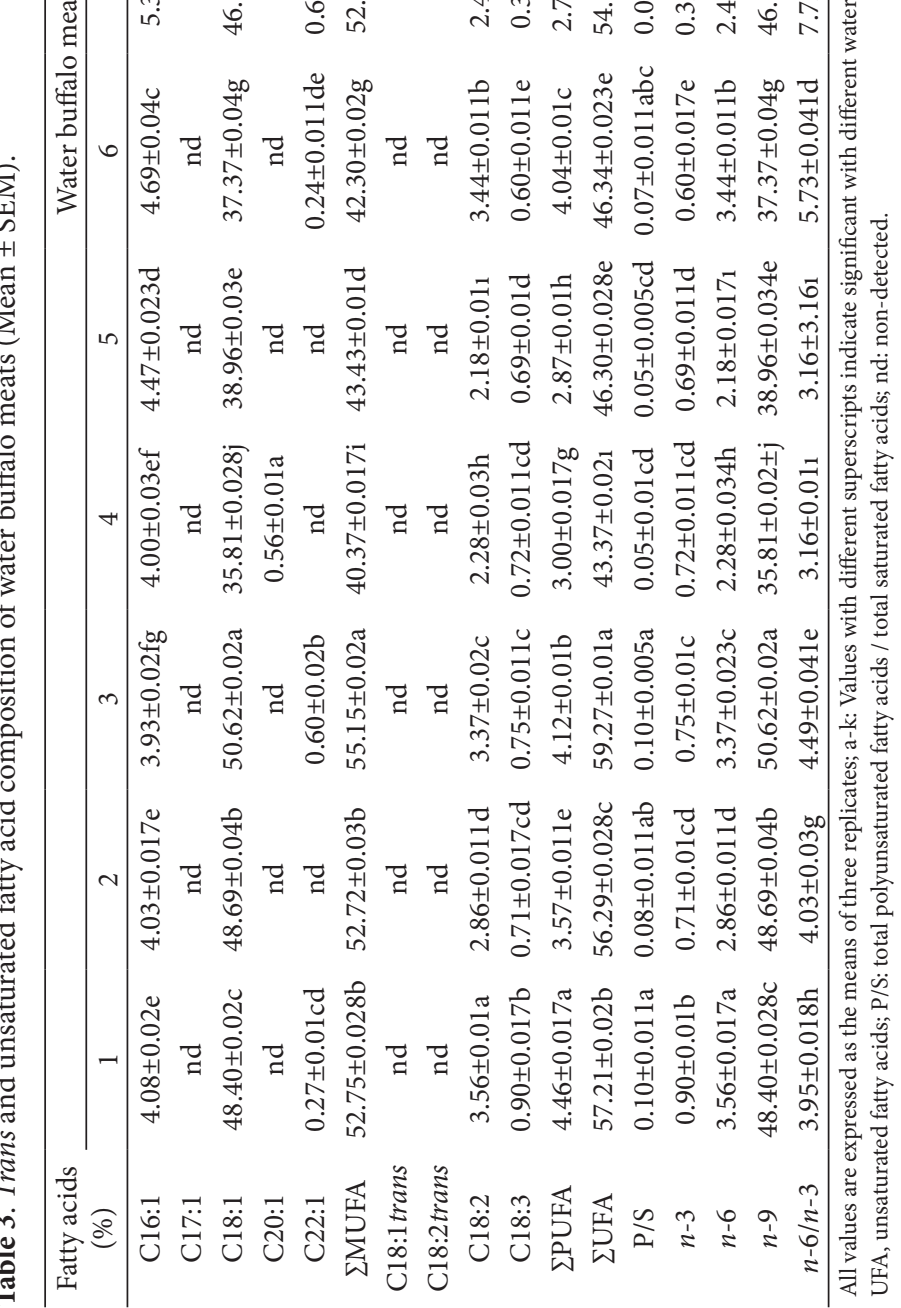


(Figure 1). Similar results were reported previously for the SFAs composition of Italian male buffaloes (Juarez et al., 2010). Caneque et al. (2001) reported that C16:0 tended to increase blood cholesterol, while C18:0 did not affect cholesterol levels. Additionally, C18:0 is an unusual SFA, which does not elevate blood cholesterol levels to the same extent as other fatty acids. This disparity can be explained by chain length, inefficient absorption, metabolism kinetics, and hepatic desaturation of stearic into oleic acid (Steinberg et al., 2003). On the other hand, Bonanome \& Grundy (1988) indicated that SFAs lauric acid (C12:0) and C14:0 can be considered as hyperlipidemias as they act to reduce cholesterol owing to their rapid conversion to oleic acid $(n-9, C 18: 1)$ and thereby, an increase in the activity of the enzyme $\Delta^{9}$-desaturase, which synthesizes C18:1 from C18:0 (Velasco et al., 2001).

A higher proportion of MUFAs and lower percentage of SFAs and PUFAs are demonstrated in Figure 2. Similarly, Spanghero et al. (2004), reported high levels of MUFAs in buffalo muscle. C18:1 content is responsible for pretty much $90 \%$ of the MUFAs in all the

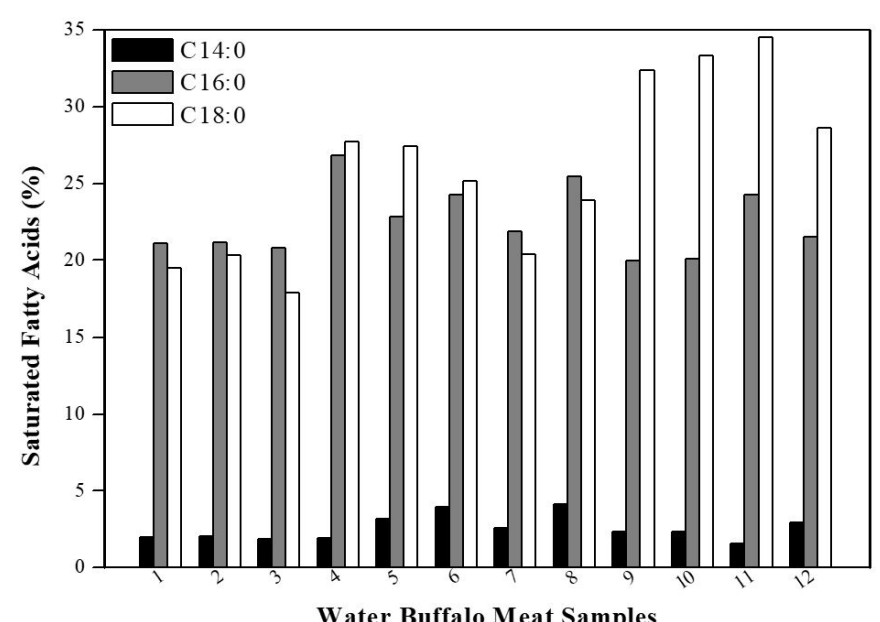

Figure 1. C14:0, C16:0, C18:0 percentage of water buffalo meats.

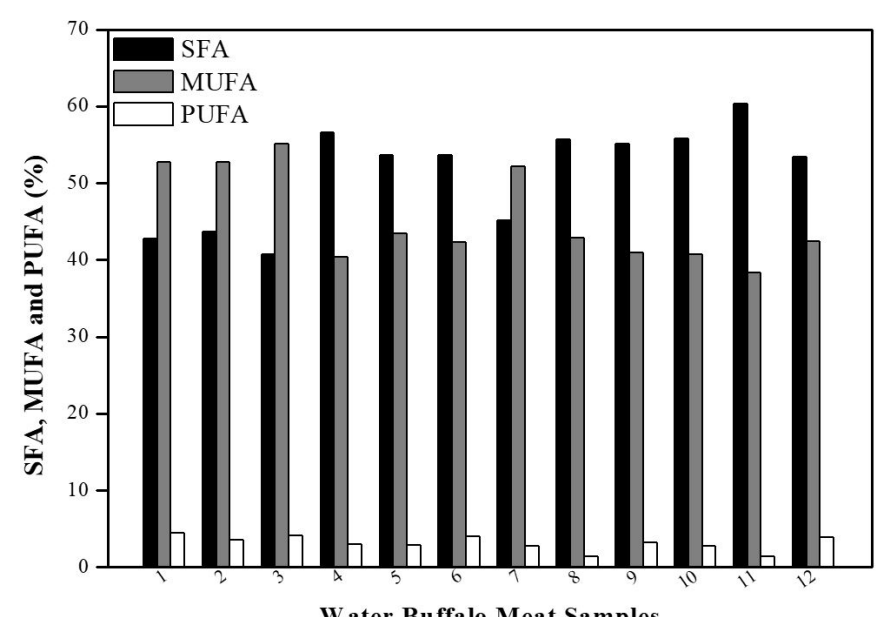

Figure 2. SFA, MUFA and PUFA percentage of water buffalo meats. buffalo meat samples. C18:1 has the beneficial effect of decreasing plasma cholesterol and LDL levels (Tejeda et al., 2008) and may slow the progression of atherosclerosis (Parthasarathy et al., 1990). Therefore, buffalo meat should be taken into account because of high oleic acid contents. The content of C16:1 in buffalo meats varied from $2.95 \%$ to $5.33 \%(\mathrm{p}<0.01)$. Minor MUFAs in the buffalo meat samples were gadoleic acid (C20:1), and erucic acid (C22:1); their contents were less than $1 \%$ of the total fatty acids. Additionally, heptadeceonic acid (C17:1) could not be determined in buffalo meats. Linoleic acid (C18:2,n-6) preponderates among the PUFAs, but linolenic acid (C18:3, n-3) is the leading minor fatty acid within PUFAs $(\mathrm{p}<0.01)$. SFAs, MUFAs, PUFAs and the contribution of specific fatty acids have health importance, and each of these dietary lipids elements has been demonstrated to affect the development of cardiovascular diseases (Garcia et al., 2008). As shown in Tables 2 and 3, the lower SFAs and the higher UFAs proportions were in numbers $1,2,3$, and 7 of water buffalo meat samples.

The P/S and $n-6 / n-3$ are generally used to evaluate the nutritional value and potential effects on consumer health of dietary fat (Giuffrida-Mendoza et al., 2015). The World Health Organization (WHO) has recommended that $n-6 / n-3$ ratio should not exceed 4.0 (Department of Health, 1994). For most of the water buffalo meat samples $(1,2,4,5,8,11$, and 12$)$, the value obtained for $n-6 / n-3 \mathrm{FA}$ is below the recommended level. These results are in accordance with those of Giuffrida-Mendoza et al. (2015). On the other hand, the ratio of $n-6 / n-3$ in other samples exceeds the value of 4.0 as described in Figure 3. Likewise, Juarez et al. (2010), and Calabro et al. (2014) cited that $n-6 / n-3$ ratio was higher than those reported by WHO. The differences in the $n-6 / n-3$ fatty acids ratio may be linked to buffaloes' diet. Finally, Lambertz et al. (2014) showed that a lower $n-6 / n-3$ ratio was observed in grass-fed compared to concentrate-supplemented animals. In addition to diet, these differences are affected by various factors such as sex, age, and breed; however, these differences were expected (Yarali et al., 2014). On the whole, the optimal nutritional value of the $n-6 / n-3$ ratio has still not been entirely evaluated for humans or animals (Calabro et al., 2014).

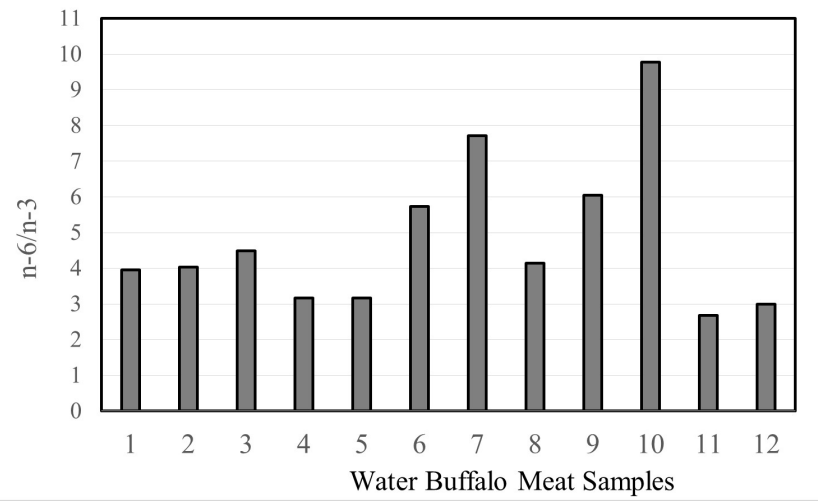

Figure 3. n-6/n-3 percentage of water buffalo meats. 


\section{Conclusion}

The present study revealed the differences in the proximate composition and fatty acid profile of the meat among water buffaloes that were raised in similar conditions and slaughtered at the same age. According to the research results, fat content of the samples was between 18.90 and $30.02 \%$. The fatty acid profile of water buffalo meat is composed of five major fatty acids; C18:1 was the highest fatty acid followed by C18:0, C16:0, C16.1, and C18:2. MUFAs were present in higher proportions than SFAs and PUFAs. Water buffalo meat may be taken into account in the diet for the prevention of heart disease owing to high MUFAs content. On the other hand, it is considered that $n-6$ and $n-3$ PUFAs are exceptionally significant in human nutrition and have a useful nutrient composition. In addition, the value obtained for $n-6 / n-3$ FA was below the recommended level. Results of this study can be useful for water buffalo meat breeders, suppliers, and consumers.

\section{References}

Association of Official Analytical Chemists - AOAC. (1990). Official methods for the analysis (15th ed.). Arlington: Association of Official Analytical Chemists.

Association of Official Analytical Chemists - AOAC. (2005). Offical Methods of Analysis (18th ed.). Arlington: AOAC International.

Awan, K., Khan, S. A., Khan, M. M., \& Khan, M. T. (2014). Effect of age on physico-chemical and sensorial quality of buffalo meat. Global Veterinaria, 13, 28-32.

Bloukas, J. G., \& Paneras, E. D. (1993). Substuting olive oil for pork back fat affects quality of low-fat frankfurters. Journal of Food Science, 58(4), 705-709. http://dx.doi.org/10.1111/j.1365-2621.1993.tb09339.x.

Bonanome, A. M. D., \& Grundy, S. M. (1988). Effect of dietary stearic acid on plasma cholesterol and lipoprotein levels. The New England Journal of Medicine, 318(19), 1244-1248. http://dx.doi.org/10.1056/ NEJM198805123181905. PMid:3362176.

Borghese, A. (2010). Development and perspective of buffalo and buffalo market in Europe and Near East. Proc. 9th World Buffalo Congress, Buenos Aires, 25-28 April. Revista Veterinaria, 21, 20-31.

Calabro, S., Cutrignelli, M. I., Gonzalez, O. J., Chiofalo, B., Grossi, M., Tudisco, R., Panetta, C., \& Infascelli, F. (2014). Meat quality of buffalo young bulls fed faba bean as protein source. Meat Science, 96(1), 591-596. http://dx.doi.org/10.1016/j.meatsci.2013.08.014. PMid:24018277.

Caneque, V., Velasco, S., Diaz, M., Perez, C., Huidobro, F., Lauzurica, S., Manzanares, C., \& Gonzalez, J. (2001). Effect of weaning age and slaughter weight on carcass and meat quality of Talaverana breed lambs raised on pasture. Animal Science, 73(01), 85-95. http://dx.doi. org/10.1017/S1357729800058082.

Department of Health. (1994). Nutritional aspects of cardiovascular disease (Report on Health and Social Subjects, 46). London: HMSO.

Du, M., \& Ahn, D. U. (2002). Effect of dietary conjugated linoleic acid on the growth rate of live birds and on the abdominal fat content and quality broiler meat. Poultry Science, 81(3), 428-433. http:// dx.doi.org/10.1093/ps/81.3.428. PMid:11902422.

Flynn, M. A., Naumann, H. D., Nolph, G. B., Krause, G., \& Ellersieck, M. (1985). The effects of meat consumption on serum lipids. Food Technology, 39, 58-113.
Folch, J., Lees, M., \& Sloane Stanley, G. H. (1957). A simple methods for the isolation and purification of total lipids from animal tissues. The Journal of Biological Chemistry, 226(1), 497-509. PMid:13428781.

Garcia, P. T., Casal, J. J., Fianuchi, S., Magaldi, J. J., Rodriguez, F. J., \& Nancucheo, J. A. (2008). Conjugated linoleic acid (CLA) and polyunsaturated fatty acids in muscle lipids of lambs from the Patagonian area of Argentina. Meat Science, 79(3), 541-548. http:// dx.doi.org/10.1016/j.meatsci.2007.12.009. PMid:22062915.

Giuffrida-Mendoza, M., Arenas de Moreno, L., Huerta-Leidenz, N., Uzcátegui-Bracho, S., Valero-Leal, K., Romero, S., \& Rodas-González, A. (2015). Cholesterol and fatty acid composition of longissimus thoracis from water buffalo (Bubalus bubalis) and Brahman-influenced cattle raised under savannah conditions. Meat Science, 106, 44-49. http://dx.doi.org/10.1016/j.meatsci.2015.03.024. PMid:25879797.

Irurueta, M., Cadoppi, A., Langman, L., Grigioni, G., \& Carduza, F. (2008). Effect of aging on the characteristics of meat from water buffalo grown in the Delta del Parana region of Argentina. Meat Science, 79(3), 529-533. http://dx.doi.org/10.1016/j.meatsci.2007.12.010. PMid:22062913.

Juarez, M., Failla, S., Ficco, A., Pena, F., Aviles, C., \& Polvillo, O. (2010). Buffalo meat composition as affected by different cooking methods. Food and Bioproducts Processing, 88(2-3), 145-148. http://dx.doi. org/10.1016/j.fbp.2009.05.001.

Kaczor, U., Borys, B., \& Pustkowiak, H. (2010). Effect of intensive fattening of lambs with forages on the fatty acid profile of intramuscular and subcutaneous fat. Czech Journal of Animal Science, 55(10), 408-419. http://dx.doi.org/10.17221/1697-CJAS.

Khan, B. B., \& Iqbal, A. (2009). The water buffalo: an underutilized source of milk and meat: a review. Pakistan Journal of Zoology Supplementary Series, 9, 517-521.

Kucukkebapci, M. (2005). Manda Yetiştiriciliği. Seminer Notu. Bandırma: Marmara Hayvancılık Araştırma Enstitüsü Müdürlüğü. [in Turkish].

Lambertz, C., Panprasert, P., Holtz, W., Moors, E., Jaturasitha, S., Wicke, M., \& Gauly, M. (2014). Carcass characteristics and meat quality of swamp buffaloes (Bubalus bubalis) fattened at different feeding intensities. Asian-Australasian Journal of Animal Sciences, 27(4), 551-560. http://dx.doi.org/10.5713/ajas.2013.13555. PMid:25049987.

Lawrie, R. A. (1998). Meat science (6th ed.). Cambridge England: Woodhead Publishing Ltd.

Lustig, R. H., Schmidt, L. A., \& Brindis, C. D. (2012). The toxic truth about sugar. Nature, 482(7383), 27-29. http://dx.doi.org/10.1038/482027a. PMid:22297952.

Mushi, D. E., Eik, L. O., Thomassen, M. S., Sørheim, O., \& Dnøy, T. (2008). Suitability of Norwegian short-tail lambs, Norwegian dairy goats and Cashmere goats for meat production-carcass, meat, chemical and sensory characteristics. Meat Science, 80(3), 842-850. http://dx.doi.org/10.1016/j.meatsci.2008.03.032. PMid:22063606.

Nanda, A. S., \& Nakao, T. (2003). Role of buffalo in the socioeconomic development of rural Asia: current status and future prospectus. Animal Science Journal, 74(6), 443-455. http://dx.doi.org/10.1046/ j.1344-3941.2003.00138.x.

Parthasarathy, S., Khoo, C., Miller, E., Barnett, J., Witztum, J. L., \& Steinberg, D. (1990). Low density lipoprotein rich in oleic acid is protected against oxidative modification: Implications for dietary prevention of atherosclerosis. Proceedings of the National Academy of Sciences of the United States of America, 87(10), 3894-3898. http:// dx.doi.org/10.1073/pnas.87.10.3894. PMid:2339129.

Pawlowicz, R., \& Drozdowski, B. (1998). Separation of geometrical isomers of unsaturated fatty acids by gas-liquid chromatography 
on CP-Sil 88 and DB-23 columns. Chemia Analityczna Warsaw, 43, 961-967.

Ponce-Alquicira, E., \& Quintero-Salazar, B. (2009). Effects of post mortem conditions on meat quality. In I. Yilmaz (Ed.), Quality of Meat and Meat Products (pp. 75-98). India: Transworld Research Network.

Raes, K., de-Smet, S., \& Demeyer, D. (2004). The effect of dietary fatty acids on incorporation of long chain polyunsaturated fatty acids and conjugated linoleic acid in lamb, beef and pork meat: a review. Animal Feed Science and Technology, 113(1-4), 199-221. http:// dx.doi.org/10.1016/j.anifeedsci.2003.09.001.

Rana, M. S., Tyagi, A., Hossain, S. A., \& Tyagi, A. K. (2012). Effect of tanniniferous Termainaliachebula extract on rumen biohydrogenation, $\mathrm{D}^{9}$-desaturase activity, CLA content and fatty acid composition in longissimus dorsi muscle of kids. Meat Science, 90(3), 558-563. http://dx.doi.org/10.1016/j.meatsci.2011.09.016. PMid:22019314.

Sariozkan, S. (2011). Türkiye’de Manda Yetiştiriciliğinin Önemi. Kafkas Üniversitesi Veteriner Fakültesi Dergisi, 17, 163-166. [in Turkish]

Setser, C. S. (1984). Color: Reflections and transmissions. Journal of Food Quality,6(3), 183-197. http://dx.doi.org/10.1111/j.1745-4557.1984. tb00824.x.

Spanghero, M., Gracco, L., Valusso, R., \& Piasentier, E. (2004). In vivo performance, slaughtering traits and meat quality of bovine (Italian Simmental) and buffalo (Italian Mediterranean) bulls. Livestock Production Science, 91(1-2), 129-141. http://dx.doi.org/10.1016/j. livprodsci.2004.07.013.

SPSS Inc. (2001). SPSS advanced models, 11.0. Chicago: SPSS Inc..
Steinberg, F. M., Bearden, M. M., \& Keen, C. L. (2003). Cocoa and chocolate flavonoids: Implications for cardiovascular health. Journal of the American Dietetic Association, 103(2), 215-223. http://dx.doi. org/10.1053/jada.2003.50028. PMid:12589329.

Tejeda, J. F., Pena, R. E., \& Andres, A. I. (2008). Effect of live weight and sex on physic-chemical and sensorial characteristics of Merino lamb meat. Meat Science, 80(4), 1061-1067. http://dx.doi.org/10.1016/j. meatsci.2008.04.026. PMid:22063837.

Turkish Statistical Institute - TUIK (2014). Çankaya: TUIK. Retrieved from www.tuik.gov.tr.

Velasco, S., Caneque, V., Perez, C., Lauzurica, S., Diaz, M. T., Huidobro, F., Manzanares, C., \& Gonzalez, J. (2001). Fatty acid composition of adipose depots of suckling lambs raised under different production systems. Meat Science, 59(3), 325-333. http://dx.doi.org/10.1016/ S0309-1740(01)00135-8. PMid:22062787.

Williams, C. M. (2000). Dietary fatty acids and human health. Annales de Zootechnie, 49(3), 165-180. http://dx.doi.org/10.1051/animres:2000116.

Yarali, E., Yilmaz, O., Cemal, I., Karaca, O., \& Taskin, T. (2014). Meat quality characteristics in Kivircik lambs. Turkish Journal of Veterinary and Animal Sciences, 38, 452-458. http://dx.doi.org/10.3906/vet1309-79.

Yousefi, A. R., Kohram, H., Zare Shahneh, A., Nik-khah, A., \& Campbell, A. W. (2012). Comparison of the meat quality and fatty acid composition of traditional fat-tailed (Chall) and tailed (Zel) Iranian sheep breeds. Meat Science, 92(4), 417-422. http://dx.doi. org/10.1016/j.meatsci.2012.05.004. PMid:22652069. 